\title{
GAMBARAN DEMOGRAFI DAN KLINIK PENDERITA NYERI NEUROPATIK YANG BERKUNJUNG DI BAGIAN POLIKLINIK SARAF DAN POLIKLINIK PENYAKIT DALAM RSU ANUTAPURA PALU
}

\author{
Nur Faisah $^{1 *}$, Masita Muchtar ${ }^{1}$, A.Asriwahyuni Lestari ${ }^{1}$ \\ ${ }^{1}$ Program Studi Pendidikan Dokter, Fakultas Kedokteran Universitas Alkhairat, Jl. Diponegoro No. 39 \\ Palu 94221, Sulawesi Tengah, Indonesia \\ *Corresponding author: Telp: +628114536960email: nunubs09@ gmail.com
}

\begin{abstract}
ABSTRAK
Nyeri neuropatik adalah nyeri yang timbul akibat langsung dari lesi atau penyakit yang mempengaruhi sistem somatosensory pada sistem saraf sentral atau perifer. Penelitian bertujuan untuk mengetahui gambaran demografi dan klinis penderita nyeri neuropati yang berkunjung di bagian Poliklinik Saraf dan Poliklinik Penyakit Dalam RSU Anutapura Palu. Metode penelitian ini adalah deskriptif kategorik dengan pendekatan cross sectional. Pengumpulan data dilakukan dengan wawancara dan observasi menggunakan kuesioner dan checklist. Penelitian dilakukan pada bulan Desember 2018 s/d Februari 2019 dan didapatkan 43 sampel. Hasil penelitian yaitu gambaran pada penderita nyeri neuropatik kelompok usia masa lansia awal (46-55 tahun) sebanyak 65,1\%, masa dewasa awal (26-35 tahun) sebanyak 9,3\% dan masa lansia akhir (56-65 tahun) sebanyak 2,3\%. Pasien nyeri neuropatik perempuan $(65,1 \%)$ dan laki-laki $(34,9 \%)$, riwayat merokok $(14,0 \%)$ dan tidak memiliki riwayat merokok $(86,0 \%)$, riwayat komsumsi alkohol $(11,6 \%)$ dan tidak memiliki riwayat konsumsi alkohol $(88,4 \%)$, memiliki riwayat diabetes melitus $(58,1 \%)$ dan tidak memiliki riwayat diabetes melitus $(41,9 \%)$ dan gambaran klinik terbanyak merasakan rasa kesemutan $(79,1 \%)$. Sebagai kesimpulan penderita nyeri neuropatik pada penelitian ini bahwa lebih banyak pada penderita neuropatik dengan riwayat DM, usia masa lansia awal dan yang memiliki gambaran klinis rasa kesemutan dan lebih sedikit pada penderita neuropatik dengan riwayat merokok dan mengkonsumsi alkohol.
\end{abstract}

Kata Kunci: Nyeri neuropatik, RSU Anutapura

\section{ABSTRACT}

Neuropathic pain is pain that arises as a direct result of a lesion or disease affecting the somatosensory system of the central or peripheral nervous system. This study aims to determine the demographic and clinical picture of patients with neuropathic pain who visited the Neurology Polyclinic and Internal Medicine Polyclinic of Anutapura Hospital Palu. This research method is descriptive categorical with the cross-sectional approach. Data were collected by interview and observation using questionnaires and checklists. The study was conducted from December 2018 to February 2019 and obtained 43 samples. The results of the study are the description of patients with neuropathic pain in the early elderly age group (46-55 years) as much as $65.1 \%$, early adulthood (26-35 years) as much as $9.3 \%$, and late old age (5665 years) as many as 2.3\%. Patients with neuropathic pain were female (65.1\%) and male (34.9\%), history of smoking (14.0\%) and had no history of smoking (86.0\%), history of alcohol consumption (11.6\%), and did not have a history of alcohol consumption (88.4\%), had a history of diabetes mellitus (58.1\%) and had no history of diabetes mellitus (41.9\%) and the most clinical picture was feeling tingling (79.1\%). In conclusion, patients with neuropathic pain in this study were more in neuropathic patients with a history of DM, early old age and who had a clinical picture of tingling and less in neuropathic patients with a history of smoking and consuming alcohol.

Keywords: Neuropathic pain, Anutapura General Hospital 


\section{PENDAHULUAN}

Nyeri neuropati adalah nyeri yang timbul akibat langsung dari lesi atau penyakit yang mempengaruhi sistem somatosensory pada sistem saraf sentral atau perifer. ${ }^{1}$ Nyeri ini menimbulkan nyeri yang khas yang bersifat epikritik (tajam dan menyetrum) yang ditimbulkan oleh serabut A delta yang rusak, ataupun protopatik seperti disestesia, rasa terbakar, parestesia dengan lokalisasi yang tidak jelas yang disebabkan oleh serabut $\mathrm{C}$ yang abnormal. Nyeri tersebut tidak selalu berlokasi atau terasa pada daerah saraf yang rusak, tapi bisa saja terjadi ditempat lain. ${ }^{2}$ Beberapa faktor resiko yang dapat menimbulkan nyeri neuropatik seperti peningkatan usia, jenis kelamin, gaya hidup yaitu riwayat merokok, riwayat komsumsi alkohol serta penyakit penyerta seperti diabetes dan faktor lainya. Penderita nyeri neuropatik yang tidak mengontrol pola makan dan gaya hidup akan terus merasakan nyeri. Dengan Gejala yang dirasakan dapat bermacam macam seperti rasa terbakar, tertusuk, dan dapat pula berupa rasa tebal dan kesemutan yang dapat membuat penderita merasa kesakitan serta menganggu aktifitaas penderita.

Epidemiologi nyeri neuropatik belum cukup banyak dipelajari, sebagian besar karena keragaman dari kondisi nyeri ini. Estimasi saat ini, nyeri neuropatik mungkin menyerang 3\% dari populasi umum. Dari 6000 sampel keluarga yang tinggal di tiga kota di Inggris, didapatkan prevalensi nyeri kronis adalah $48 \%$ dan prevalensi nyeri neuropatik adalah $8 \%$. Responden dengan nyeri neuropatik kronis lebih banyak perempuan, dengan usia yang cukup tua, belum menikah, tidak memiliki kualifikasi pendidikan, dan merupakan perokok. $^{3}$

Angka kejadian nyeri neuropatik di indonesia setiap tahunya berubah. Mulai tahun 2008 dengan angka kejadian 20,3\%, tahun 2012 dengan angka kejadian 26\% dan pada tahun 2014 dengan angka kejadian $28 \%$. Untuk kota palu sendiri yaitu di RSU Anutapura palu selalu meningkat mulai tahun 2013 dengan angka kejadian 35 penderita, tahun 2014 dengan angka kejadian 48 penderita dan pada tahun 2015 dengan angka kejadian 76 penderita kemudian pada tahun 2016 dengan angka kejadian 110, hingga tahun 2017 dengan angka kejadian 117 penderita. $^{4}$

Nyeri neuropati menurut jenis kelamin lebih banyak terjadi pada perempuan. Pada teorinya, perbedaan hormon antara laki-laki dan perempuan mempengaruhi timbulnya neuropati. Tingginya kadar estrogen pada perempuan dapat menganggu penyerapan iodium yang berperan dalam proses pembentukan myelin saraf. ${ }^{5}$

Pada usia lanjut berhubungan dengan akumulasi kerusakan akibat radikal bebas seperti peningkatan kadar lipid peroksida dan perubahan aktivitas enzim yang diakhiri dengan kerusakan jaringan pada usia lanjut. Peningkatan usia juga merangsang proses degenerasi dan menyebabkan keusakan sel saraf. Perubahan baik pada serabut saraf kecil maupun serabut saraf besar menimbulkan kerentanan usia lanjut terhadap nyeri neuropati. ${ }^{5}$

Penelitian ini bertujuan untuk mengetahui gambaran demografi dan klinis penderita nyeri neuropati yang berkunjung di bagian Poliklinik Saraf dan Poliklinik Penyakit Dalam RSU Anutapura Palu.

\section{METODOLOGI}

Metode penelitian yang digunakan adalah deskriptif kategorik dengan pendekatan "cross sectional" yang bertujuan untuk gambaran demografi dan klinik pada subjek yang terdiagnosis menderita Nyeri Neuropatik dibagian Poliklinik Saraf dan Poliklinik Penyakit Dalam RSU Anutapura Palu.

Subyek Penelitian adalah semua penderita Nyeri Neuropatik yang berkunjung dibagian Poliklinik Saraf dan Poliklinik Penyakit Dalam di RSU Anutapura Palu, yang memenuhi kriteria penelitian. Berdasarkan perhitungan dengan rumus Teknik Slovin diperoleh jumlah sampel sebanyak 43 orang. Metode pengambilan mengunakan cara consecutive sampling.

Analisis data menggunakan deskriptif dengan hasil berupa frekuensi dan persentase yang disajikan dalam bentuk tabel. Data yang diperoleh terdiri dari usia, jenis kelamin, 
riwayat merokok, riwayat konsumsi alkohol, riwayat penyakit diabetes melitus dan gambaran klinik pada penderita nyeri neuropatik.

\section{HASIL DAN PEMBAHASAN}

HASIL

\section{Gambaran Penderita Nyeri Neuropatik} Berdasarkan Usia

Untuk mengetahui gambaran penderita nyeri neuropatik berdasarkan usia dapat dilihat pada tabel berikut ini:

Tabel 1. Distribusi penderita Nyeri Neuropatik berdasarkan usia

\begin{tabular}{ccc}
\hline \multirow{2}{*}{ Kelompok Usia } & \multicolumn{2}{c}{ Nyeri Neuropatik } \\
\cline { 2 - 3 } & $\mathrm{N}$ & $\%$ \\
\hline Masa Dewasa Awal (26-35 Tahun) & 4 & $9,3 \%$ \\
Masa Dewasa Akhir (36-45 Tahun) & 10 & $23.3 \%$ \\
Masa Lansia Awal (46-55 Tahun) & 28 & $65,1 \%$ \\
Masa Lansia Akhir (56-65 Tahun) & 1 & $2,3 \%$ \\
\hline Total & 43 & $100.0 \%$ \\
\hline
\end{tabular}

Pada Tabel 1 Dapat dilihat bahwa dari 43 penderita Nyeri Neuropatik yang terbanyak ditemukan pada kelompok usia masa lansia awal(46-55 tahun) yaitu sebanyak $(65,1 \%)$, Masa dewasa akhir (36-45) tahu sebanyak (23,3\%) selanjutnya masa dewasa Awal (26-35 tahun) sebanyak $(9,3 \%)$ dan terendah masa lansia akhir (56-65 tahun) sebanyak (2,3\%).

2. Gambaran Penderita Nyeri Neuropatik Berdasarkan Jenis Kelamin di RSU Anutapura Palu

Untuk mengetahui gambaran penderita nyeri neuropatik berdasarkan jenis kelamin dapat dilihat pada tabel berikut ini:

Tabel 2. Distribusi penderita Nyeri Neuropatik berdasarkan Jenis Kelamin

\begin{tabular}{ccc}
\hline \multirow{2}{*}{ Jenis Kelamin } & \multicolumn{2}{c}{ Dermatitis Kontak } \\
\cline { 2 - 3 } & $\mathrm{N}$ & $\%$ \\
\hline Laki-laki & 15 & $34.9 \%$ \\
Perempuan & 28 & $65.1 \%$ \\
\hline Total & 43 & $100.0 \%$ \\
\hline
\end{tabular}

Pada Tabel 6 diatas didapatkan, penderita Nyeri Neuropatik terbanyak adalah perempuan $(65,1 \%)$ dan laki-laki $(34,9 \%)$.

\section{Gambaran Penderita Nyeri Neuropatik Berdasarkan Riwayat Merokok}

Untuk mengetahui gambaran penderita nyeri neuropatik berdasarkan riwayat merokok dapat dilihat pada Tabel berikut ini:
Tabel 3. Distribusi Penderita Nyeri Neuropatik Berdasarkan Riwayat Merokok

\begin{tabular}{ccc}
\hline \multirow{2}{*}{ Riwayat Merokok } & \multicolumn{2}{c}{ Nyeri Neuropatik } \\
\cline { 2 - 3 } & $\mathrm{N}$ & $\%$ \\
\hline Ada & 6 & $14.0 \%$ \\
Tidak Ada & 37 & $86.0 \%$ \\
\hline Total & 43 & $100.0 \%$ \\
\hline
\end{tabular}

Pada Tabel 3 di atas, yang memiliki riwayat merokok pada penderita Nyeri Neuropatik sejumlah $(14,0 \%)$ dan yang tidak memiliki riwayat merokok pada penderita Nyeri Neuropatik sejumlah $(86,0 \%)$.

\section{Gambaran Penderita Nyeri Neuropatik} Berdasarkan Riwayat Konsumsi Alkohol

Untuk mengetahui gambaran penderita nyeri neuropatik berdasarkan riwayat konsumsi alkohol dapat dilihat pada tabel berikut ini:

Tabel 4. Distribusi penderita Nyeri Neuropatik Berdasarkan Riwayat Konsumsi Alkohol

\begin{tabular}{|c|c|c|}
\hline \multirow{2}{*}{$\begin{array}{l}\text { Riwayat Konsumsi } \\
\text { Alkohol }\end{array}$} & \multicolumn{2}{|c|}{$\begin{array}{c}\text { Nyeri } \\
\text { Neuropatik }\end{array}$} \\
\hline & $\mathrm{N}$ & $\%$ \\
\hline Ada & 5 & $11.6 \%$ \\
\hline Tidak Ada & 38 & $88.4 \%$ \\
\hline Total & 43 & $100.0 \%$ \\
\hline
\end{tabular}

Pada Tabel 4 di atas, yang memiliki riwayat konsumsi Alkohol pada penderita Nyeri Neuropatik sejumlah $(11,6 \%)$ dan yang 
tidak memiliki riwayat konsumsi Alkohol pada penderita Nyeri Neuropatik sejumlah $(88,4 \%)$.

\section{Gambaran Penderita Nyeri Neuropatik Berdasarkan Riwayat Diabetes Melitus}

Untuk mengetahui gambaran penderita nyeri neuropatik berdasarkan riwayat diabetes melitus dapat dilihat pada tabel berikut ini :

Tabel 5. Gambaran penderita Nyeri europatik berdasarkan Riwayat Diabetes Melitus

\begin{tabular}{ccc}
\hline \multirow{2}{*}{$\begin{array}{c}\text { Riwayat Diabetes } \\
\text { Melitus }\end{array}$} & \multicolumn{2}{c}{$\begin{array}{c}\text { Nyeri } \\
\text { Neuropatik }\end{array}$} \\
\cline { 2 - 3 } & $\mathrm{N}$ & $\%$ \\
\hline Ada & 25 & $58.1 \%$ \\
Tidak Ada & 18 & $41.9 \%$ \\
\hline Total & 43 & $100.0 \%$ \\
\hline
\end{tabular}

Pada Tabel 5 di atas, yang memiliki riwayat diabetes melitus pada penderita Nyeri Neuropatik sejumlah $(58,1 \%)$ dan yang tidak memiliki riwayat diabetes melitus pada penderita Nyeri Neuropatik sejumlah $(41,9 \%)$.

\section{Gambaran Penderita Nyeri Neuropatik Berdasarkan gambaran klinis Klinis}

Untuk mengetahui gambaran penderita nyeri neuropatik berdasarkan gambar klinis dapat dilihat pada tabel berikut ini :

Tabel 6. Gambaran penderita Nyeri Neuropatik berdasarkan gambaran klinik

\begin{tabular}{lcc}
\hline \multirow{2}{*}{ Gambaran Klinik } & \multicolumn{2}{c}{ Nyeri Neuropatik } \\
\cline { 2 - 3 } & $\mathrm{N}$ & $\%$ \\
\hline Rasa Kesemutan & 34 & $79.0 \%$ \\
Rasa Tebal & 2 & $4.7 \%$ \\
Rasa Terbakar & 1 & $2.3 \%$ \\
Rasa Tertusuk & 6 & $14.0 \%$ \\
\hline \multicolumn{1}{c}{ Total } & 43 & $100.0 \%$ \\
\hline
\end{tabular}

Pada Tabel 6 di atas, gambaran klinik pada penderita Nyeri Neuropatik paling banyak ditemukan yang merasakan Rasa Kesemutan sebanyak $(79,0 \%)$, dan yang merasakan rasa tertusuk sebanyak $(14,0 \%)$, yang merasakan rasa tebal sebanyak $(4,7 \%)$ dan terrendah Rasa Terbakar sebanyak (2,3\%).

\section{PEMBAHASAN}

1. Gambaran penderita Nyeri Neuropatik berdasarkan usia.

Hasil penelitian berdasarkan usia terhadap penderita nyeri neuropatik terbanyak ditemukan pada kelompok usia masa lansia awal yaitu 46 - 55 tahun dengan presentase $(65,1 \%)$. Hal ini dikarenakan Pada usia lanjut berhubungan dengan akumulasi kerusakan akibat radikal bebas seperti peningkatan kadar lipid peroksida dan perubahan aktivitas enzim yang diakhiri dengan kerusakan jaringan pada usia lanjut.

Peningkatan usia juga merangsang proses degenerasi dan menyebabkan kerusakan sel saraf. Perubahan baik pada serabut saraf kecil maupun serabut saraf besar menimbulkan kerentanan usia lanjut terhadap nyeri neuropati.

Penelitian ini juga Sejalan dengan penelitian yang dilakukan oleh Anisa F Amalia dkk tahun 2016 yaitu nyeri neuropatik terbanyak terjadi pada kelompok masa lansia $46-55$ tahun. $^{6}$

\section{Gambaran penderita Nyeri Neuropatik berdasarkan jenis kelamin}

Hasil penelitian berdasarkan jenis kelamin pada penderita Nyeri Neuropatik paling banyak didapatkan pada pasien yang berjenis kelamin perempuan. Presentase jenis kelamin perempuan pada penderita Nyeri Neuropatik $(65,1 \%)$ sedangkan pada laki-laki $(34,9 \%)$.

Menurut teori, perbedaan hormon antara laki-laki dan perempuan mempengaruhi timbulnya neuropati. Tingginya kadar estrogen pada perempuan dapat menganggu penyerapan iodium yang berperan dalam proses pembentukan myelin saraf. Hal ini juga biasa disebakan karena pengaruh adanya riwayat kehamilan dan presentase timbunan lemak badan pada wanita lebih besar dibandingkan dengan pria dan tentu saja hal ini mempengaruhi status gizi pada perempuan. ${ }^{5}$

Penelitian ini sejalan dengan penelitian yang dilakukan oleh moulin dkk tahun 2002 yang mengatakan bahwa prevelensi nyeri pada perempuan adalah 4\% lebih besar dibanding laki-laki. ${ }^{7} \mathrm{Hal}$ ini juga sejalan pada penelitian 
yang dilakukan oleh Anisa F Amalia dkk tahun 2016 bahwa sebagian besar pasien nyeri yang didapatkan pada hasil penelitiannya adalah perempuan yaitu berjumlah 618 pasien atau sebesar $58.7 \%$, sedangkan jumlah pasien nyeri pada laki-laki berjumlah 434 pasien atau sebesar $41.3 \%{ }^{6}$

Hal tersebut dapat dikatakan insidensi nyeri neuropatik pada perempuan yang memiliki nilai yang konstan yaitu lebih tinggi dibandingkan jumlah pasien nyeri neuropatik pada laki-laki. Mekanisme yang terkait adalah adanya faktor biologis yaitu hormon dalam modulasi nyeri dan adanya faktor psikososial seperti peran jenis kelamin.

\section{Gambaran penderita Nyeri Neuropatik berdasarkan riwayat merokok}

Hasil penelitian menurut riwayat merokok terhadap penderita nyeri neuropatik adalah tertinggi tidak memiliki riwayat merokok dibanding yang tidak merokok. Hal ini sejalan dengan Marlenny bahwa penderita nyeri neuropatik tertinggi adalah tidak memiliki riwayat merokok yaitu 30 orang dari jumlah sampel 45 orang. ${ }^{8}$

\section{Gambaran penderita Nyeri Neuropatik berdasarkan riwayat konsumsi alkohol}

Hasil penelitian menurut riwayat konsumsi alkohol terhadap penderita nyeri neuropatik adalah tertinggi tidak memiliki riwayat konsumsi alkohol dengan presentase $(88,4 \%)$ sedangkan yang memiliki riwayat konsumsi alkohol hanya sebesar $(11,6 \%)$. Tidak ditemukanya penelitian yang membahas tentang variabel riwayat konsumsi alkohol dengan nyeri neuropatik. Namun, riwayat konsumsi alkohol sering ditemukan pada pasien nyeri neuropatik. Tetapi teori mengungkapkan Konsumsi alkohol berlebih dan berkepanjangan juga meningkatkan risiko mengalami nyeri neuropatik.

Gaya hidup pada pasien neuropati belum diteliti secara mendalam namun riwayat konsumsi alkohol sering ditemukan pada pasien nyeri neuropatik dan orang yang mengkomsumsi alkohol dapat menyebabkan terjadinya defisiensi mikronutrisi yaitu tiamin, penurunan penyerapan tiamin pada intestinal, penurunan cadangan tiamin di hati dan mempengaruhi fosforilasi tiamin. Alkohol juga menyebabkan penurunan ambang nosiseptor, peningkatan stres oksidatif dan memicu pelepasan proinflamasi seperti sitokin yang mengaktivasi protein kinase $\mathrm{C}$.

\section{Gambaran penderita nyeri neuropatik} berdasarkan riwayat diabetes melitus

Hasil penelitian menurut riwayat diabetes melitus terhadap penderita nyeri neuropatik adalah tertinggi memiliki riwayat diabetes melitus dengan presentase $58,1 \%$ sedangkan yang tidak memiliki riwayat diabetes melitus hanya sebesar $41,9 \%$. Hal ini sejalan dengan penelitian yang dilakukan Penelitian yang dilakukan Darsana di RSU Sanglah Denpasar memperlihatkan terdapat korelasi bermakna $(\mathrm{r}=0,303 ; p=0,004)$ antara lama DM dengan Neuropati Diabetik Perifer (NDP). ${ }^{9}$

Berdasarkan penelitian pada 60 diabetesi yang terbagi menjadi kelompok durasi DM $<5$ tahun, 5-10 tahun, dan $>10$ tahun, didapatkan bahwa insiden nyeri neuropatik meningkat masing-masing dua kali lipat pada setiap kelompok.

Hal ini menunjukkan bahwa penderita yang mengalami nyeri neuropatik memilki riwayat diabetes melitus yang telah lama diderita dengan kurun waktu 5-10 tahun menderita diabetes melitus dan beberapa penelitian menunjukkan adanya hubungan antara durasi seseorang yang terpapar hiperglikemia akan menyebabkan terjadinya komplikasi seperti nyeri neuropati.

\section{Gambaran penderita nyeri neuropatik berdasarkan gambaran klinik}

Hasil penelitian berdasarkan gambaran klinis terhadap penderita nyeri neuropatik yang tertinggi yaitu rasa kesemutan dengan presentase $(79,1 \%)$ kemudian rasa tertusuk dengan presentase $(14,0 \%)$ dan rasa tebal yaitu $(4,7 \%)$, gambaran klinik terendah yang didapatkan pada penelitian ini adalah rasa terbakar yaitu degan presentase $(2,3 \%)$.

Penelitian ini sejalan dengan penelitian yang dilakukan di RSUP Prof Dr. R.D. Kandou Manado juga mendapatkan gejala 
klinis yang paling banyak yaitu gejala klinis kesemutan atau kram, yaitu sebanyak 70 orang $(84,3 \%)$ dari keseluruhan pasien. ${ }^{10}$

\section{KESIMPULAN}

Berdasarkan hasil penelitian dari 43 penderita nyeri neuropatik yang berkunjung di Bagian Poliklinik saraf dan poliklinik penyakit dalam RSU Anutapura Palu tentang Gambaran penderita nyeri neuropatik yang berkunjung di Bagian Poliklinik saraf dan poliklinik penyakit dalam RSU Anutapura Palu kesimpulannya sebagai berikut:

1. Gambaran penderita nyeri neuropatik berdasarkan usia terbanyak pada kelompok usia masa lansia awal 46-55 tahun sebanyak $(65,1 \%)$, Masa dewasa akhir 36-45 tahun sebanyak $(23,3 \%)$ Selanjutnya masa dewasa Awal 26-35 tahun sebanyak $(9,3 \%)$ dan terendah masa lansia akhir 56-65 tahun sebanyak (2,3\%).

2. Gambaran penderita nyeri neuropatik berdasarkan Jenis kelamin yang terbanyak di dapatkan pada perempuan dari pada laki-laki

3. Gambaran penderita nyeri neuropatik berdasarkan riwayat merokok di dapatkan hanya sebagian kecil yang mempunyai riwayat merokok. selebihnya tidak memiliki riwayat merokok.

4. Gambaran penderita nyeri neuropatik berdasarkan riwayat konsumsi alkohol di dapatkan hanya sebagian kecil yang mempunyai riwayat komsumsi alkohol. Lebih banyak yang tidak komsumsi alkohol.

5. Gambaran penderita nyeri neuropatik berdasarkan riwayat diabetes melitus di dapatkan lebih banyak memiliki riwayat diabetes melitus dibanding yang tidak memiliki riwayat diabetes melitus.

6. Gambaran penderita nyeri neuropatik lebih banyak di temukan pada penderita yang memiliki gambaran klinis rasa kesemutan.

\section{DAFTAR PUSTAKA}

1. Jensen, et al. (2011). A genome-wide association study suggests an association of Chr8p21.3 (GFRA2) with diabetic neuropathic pain.

2. Richeimer. S. (2017). Gambaran klinis nyeri neuropatik.

3. Gilron, I. (2006). Motor imagery and its effect on complex regional pain syndrome: an integrativereview.

4. RSU Anutapura Palu "Kasus Nyeri Neuropatik di Anutapura Palu : RSU Anutapura Palu 2017.

5. Azhary, H. (2010). Peripheral Neuropathy: Differential Diagnosis and Management.

6. Amalia AF, Runtuwene T, Kembuan MAHN. Profil nyeri di poliklinik saraf RSUP Prof. Dr. R. D. Kandou Manado periode 1 Januari 2014 - 31 Desember 2014. e-CliniC. 2016;4(2). doi:10.35790/ecl.4.2.2016.14593

7. Moulin DE, Clark AJ, Speechley M, Morley-Forster PK. Chronic pain in Canada - Prevalence, treatment, impact and the role of opioid analgesia. Pain Res Manag. 2002;7(4):179-184. doi:10.1155/2002/323085

8. Marlenny MD, Anwar Y, Sjahrir H. Identifikasi Nyeri Neuropatik Dengan Memakai Skala Nyeri Leeds Assesment Of Neuropathic Symptoms And Signs ( Lanss ) Pada Penderita Nyeri Punggung Bawah Kronik. 2010;27(3).

9. Darsana IN. Korelasi positif kadar asam urat serum tinggi dengan neuropati diabetik perifer pada penderita dm tipe 2 di rumah sakit umum pusat sanglah denpasar. Published online 2014.

10. Hutapea FS, Kembuan MAHN, P.S. JM. Gambaran klinis neuropati pada pasien diabetes melitus di Poliklinik Neurologi RSUP Prof. Dr. R. D. Kandou periode Juli 2014 - Juni 2015. e-CliniC. 2016;4(1). doi:10.35790/ecl.4.1.2016.12115 